УДК 398.3:821.163.3-31.09

https://doi.org/10.55302/MF2179159k

Оливера Каевска

\title{
ОБИЧАИТЕ И ВЕРУВАЊАТА ВО МАРИОВСКО ПРИКАЖАНИ ВО РОМАНОТ „КРПЕН ЖИВОТ“ ОД СТАЛЕ ПОПОВ
}

Апстракт: Во овој труд ќе стане збор за обичаите и верувањата во Мариовско прикажани во романот Крпен живот од Столе Попов. Романот Крпен живот претставува широка слика за мариовскиот селски живот. Особено внимание е посветено на начинот на живеење, на обичаите, на верувањата на едно типично селско, мариовско семејство, при крајот на деветнаесеттиот и на почетокот на дваесеттиот век.

Клучни зборови: верувања, обичаи, селски бит, ора, гајдаџии.

Стале Попов ѝ припаѓa на првата генерација повоени македонски писатели. Тој, иако во поодминати години, по Втората светска војна посериозно се зафатил со пишување на прозни дела, оставајќи зад себе бројни и вредни остварувања, меѓу кои е и неговиот прв роман Крпен живот, во чија основа е содржана битово-социјална тематика. Во него е претставен животот на семејството Сукаловци од мариовското село Витолиште, а токму поради тоа овој роман се доживува како своевидна сага.

Во романот се среќаваме со голем број обичаи и верувања кои се предадени според принципите на реализмот. Може да се каже дека авторот гради реалистични слики од секојдневниот живот преку кои ја реконструира автентичноста, наметнувајќи го прашањето за границата меѓу етнографијата и книжевноста. Ова е очигледно во романот кој претставува продлабочена студија за народниот живот во Мариово со сите негови белези. Романот е широка панорама на народниот бит на мариовскиот човек и на неговата живеачка, со сите нејзини етнолошки и фолклорни обележја, со карактеристиките на луѓето и обичаите во мариовското празнично и делнично секојдневие, со патријархалниот морал напластен со вековни предрасуди, со етичноста и менталитетот на селското меѓусебно однесување. Во оваа смисла, Димитар Митрев истакнува дека Крпен живот е литература, која, со сето во себе, е свртена кон битот и средината, кон живиот живот и живиот говор на еден регион, каков што е мариовскиот крај (Митрев, 1966). Писмото на Стале Попов, вели тој, за неговото проникнување во битот на мариовското село, неговото согледување на селото и селанското, е пречистено од примеси на идеализација, на романтика, на пасторалност и идиличност наспрема минатото на селскиот бит. Тој е објективен прикажувач на животот што го носи во себе и знае во исто време дека и во тој живот настанале промени.

Романот е напишан на еден од најспецифичните наши дијалекти каков што е мариовскиот, со што се задоволува една дијалектичка потреба на нашиот литературен развиток, а токму во ова се состои значајноста на овој роман. Крпен живот е литература блиска до потходот и стилот на народната приказна и содржи бројни елементи и обележја од чисто етнографски или 
фолклорен карактер. Едноставно речено: еден живот е согледан и претставен во раскажувачки вид со свои очи и е прекршен низ призмата на најнепосредно вживување и вчуствување, истакнува Митрев. Ништо туѓо и ништо странично не застанува меѓу животот и неговиот изобразувач. Елиминиран е секаков вештачки елемент во погледот кон селото, кон едноставноста на селскиот бит, затоа и сѐ што е селско во селанството го наоѓа својот верен, својот природен израз. Затоа на многу страници од романот се сугерира автентичност, се претставуваат сурови делови извлечени направо од селската стварност, без секакво настојување да бидат украсени, па дури и пречистени од маловажното (Митрев, 1980).

Пишувајќи за Крпен живот, Митрев со право забележува дека многу страници во себе носат богати етнографски и фолклорни обележја што се добиваат од разновидни детални описи на материјалниот народен живот, на народните традиции и народната душевност. Со сигурност може да се каже дека двата дела во романот, кои изобилуваат со етнографски и со фолклорни податоци, се прикажани со таква студиозност и со таков разновиден вид, што на авторот можат да му завидат и најдобрите специјалисти, етнографи и фолклористи. Или, кажано поинаку, ниту во една етнографска студија кај нас не е даден таков обилен материјал и толку живо одухотворен. Дури може да се забележи дека романот прави силен впечаток и со податоци коишто спаѓаат во областа на најспецифичната етнопсихологија.

Ликовите во Крпен живот не се апстрактно воопштени селани, туку типични и јарко индивидуализирани живи Мариовци, како што истакнува Митрев (Митрев, 1966). Поставени во својата природна средина и откриени во својата најприсутна животна сушност, тие не можат да не бидат такви. Неконвенционални, типични, индивидуализирани, животно убедливи, со еден збор: реалистични. Секој од овде изградените ликови го гледа светот по своему, а не како би го видел авторот. Кога ни раскажува за нив, вели Митрев, авторот умее да се соживее со нивната положба, да заговори така како што би ни говореле тие, со живи, природни, самосвојствени дијалози. Читателот го слуша нивниот глас, вели тој, а не темброт на еден книжен изговор, не фрази, не фалш говор. Пожива и пораздвиженоизнесена разговорност, да речеме од онаа на епизодниот дедо Петко, не е дадена досега во нашата прозна белетристика. Поточен и од танкости погоден природен селански говор не познава ни едно наше прозно дело, како што не познава и таков сигурно воден дијалог кој создава впечаток за разговор што се води не меѓу литературни јунаци, ами меѓу живи луѓе. Мариовскиот говор во романот е толку веродостоен и автентичен што секој дијалог даден во романот е негов доказ. Народната синтакса не добила таква примена никогаш во нашата литература, па затоа и не сме можеле, до појавата на овој роман, да ја почувствуваме со таква сила епската виталност, еластичноста и ведрината на живиот народен јазик. Единствен конкурент е само јазикот од народните приказни, додава Митрев (Митрев, 1980).

Во Крпен живот е прикажан животот на едно типично селско, мариовско семејство, а целта е да се претстават обичаите и верувањата во мариовското село Витолиште, изразени преку животот на семејството 
Сукаловци. Во него, етнографско-антрополошкото гледиште на културата во голема мера се однесува на обичаите и на однесувањата на одредена популација, што во потесна смисла значи дека културата на таа социјална група опфаќ: религиозни верувања, јазик, работни навики, научени однесувања, идеи што се прифатени од заедницата и сл. Ваквата поврзаност недвосмислено покажува дека во романот постојат бројни детерминации на културата на одредена средина, како и на нејзиното влијание врз одредување на однесувањето на човекот. Поаѓајќи од овие размислувања, кои се однесуваат на меѓусебната корелација меѓу културата и општеството, треба да се каже дека културата претставува форма на човековото дејствување и на човековата активност, а со тоа влијае и врз членовите на општеството, поттикнувајќи и одредени промени во него. Токму затоа треба да се одбележи дека е автентичен писателовиот потход во прикажувањето на фолклорното и на етнографското, наспроти: историското, борбеното, социјалното и националното.

Стале Попов, во овој роман, од повеќе можни аспекти го открива материјалното и моралното егзистирање, со широко разгрнување на народните традиции и обичаи, на народната душевност на мариовскиот човек, на етнопсихологијата на тој човек, кој блика од хуманизам и непорочност. Но, исто така, авторот нѐ запознава со низа верувања, легенди и преданија. Познато е дека легендите претставуваат дел од традициите на одделните култури и со време се менуваат за да ги задржат: својата свежина, виталност и реализмот. Во овој случај ја имаме легендата за настанувањето на мариовското централно село Витолишча, со која започнува и романот. Во неа се зборува дека многу одамна, а не се знае кога, крај реката Црна, во селото Разлог, живееле тројца браќ: Раде, Гале и Вите. Тие тогаш се занимавале со сточарство, лов, пчеларство и по малку со земјоделие. Кога виделе дека земјата им се испостила, а тревата речиси секоја година горела од жешкото сонце, тие решиле да побараат подобро место за живеење. На вакво размислување ги навеле и нивните коњи, кои бегајќи од низината крај Црна, летно време накачувале горе по Зелка, Гурѓ́шта, Перун и Трибор, барајќи сочна трева. Прибирајќ́ ги коњите, Вите видел убави ораници со богата паша, па една есен си направил меќанец (колипка) во полите на овие високи планини, таму презимил, а напролет си ги дотерал и овците и говедата. Така, Вите се заселил во оваа котловинка и ги удрил темелите на сегашното Витолишча, па по неговото име го добила името и самото село.

Тема на романот е животот на семејството Сукаловци од мариовското село Витолиште, а идејата е да се даде целосна слика на животот (обичаите, јазикот, фолклорот) во мариовските села при крајот на XIX и на почетокот на XX век, со што романов претставува жива енциклопедија на животот и луѓето од Мариовско, а изобилува со етнографски и со фолклорни обележја. Дејството е лоцирано во далечната 1898 година и претставува разоткривање на сликата на мариовскиот селски бит од самиот крај на минатиот XIX век. Во романот, Стале Попов дава посебен опис на една мариовска куќа, во тоа време, во која живеело семејството Сукаловци. Него го сочинувале најстариот 
брат Стојо, жена му Митра и децата, четириесетгодишниот вдовец Илко и најмалиот брат Трајко (исто така вдовец).

Во романот особено внимание е посветено на: начинот на живеење, обичаите, традицијата, а сето тоа е прикажано преку двата женски лика, Доста и Митра, преку кои е прикажана типичната македонска жена од тоа време, столбот на семејството и домот, носителот на традицијата, но и носителот на новото време и промените. Токму затоа, литературниот критичар Миодраг Друговац вели: „регионалистички (да), но осовремен, а историски нужен заради пополнување на празнините во континуитетот на македонската литература“ (Друговац, 1968, 280-289).

Најнапред авторот го открива ликот на Илко Сукалов, кој, во тоа време, на свои четириесет години станува вдовец, а според верувањата, судбината му определила да се преженува, т.е. да води крпен живот, живот со втора жена. Тој решил да се прежени со Рожденката Доста на која исто така ѝ умрел мажот. За таа цел, го испраќа дедото Петко Балето како проводаџија, сводничар, да појде до Рожден, верувајќи во неговите сводничарски моќи некако да ја убеди, да ја заврти Господ надесно Рожденката и да стори себап да се прожени.

Дедото Петко Балето е прикажан како страшен „шмеќар“, кој шеретува во анчето на сина си и си прикажува со други Мариовци, а Мариовци, како што вели нараторот, прикажуваат за што друго ако не за жени. Тој се нафаќа да биде стројничар (наводаџија) и да ја заврши работата за Илка, само затоа што и тој ќе заработи некоја лира, ќе падне некоја бела меџудија и за него.

Авторот ја опишува облеката на Доста Рожденката како вдовица, дека таа била по „ѓупски“ облечена. Главата ѝ била преврзана со црна шамија, немала ни прцле, ни кркми, ни цулувци, ни појас, ни сагија, ни гуна. Една вреќа, конопна и во неа нешто како човек, жена, којзнае што, права Ѓ упка.

Обичајот налагал ако жената се нафатела да се омажи, од идниот маж да бара лири, вранги, бели меџудии. На стројничарот требало да му се купи едно рало чевли. За другите поблиски роднини, по некој дар да им дарува идниот зет. Идните сопружници, вдовецот Илко и вдовицата Доста, за првпат се виделе во куќата на дедото Ристета Карабуклијата во Рожден, близок роднина на Доста. Според обичаите, првата средба била секогаш преку стројничари и на таа средба се договарало за идниот брак и за задолженијата на сопружниците и за нивните семејства од двете страни, се разбира ако идните сопружници се бендисале еден со друг и се согласеле за брак. Зетот ѝ дава лири на невестата како доказ дека таа од таа судна вечер е капарисана, свршена за него и армасувањето завршува со честитање.

Следниот обичај прикажан во овој роман е кога идната невеста за првпат влегува во куќата на својот иден маж. Во конкретниов случај на избраните ликови на вдовец и вдовица, тие посакуваат целата работа да се заврши што побргу со помала помпезност. Вдовицата Доста најавува дека нема руба за товарање или популарниот чеиз што секоја мома го носи кај идниот маж. Таа не сакала да се мие и коцли да клава т.е. да се разубавува. Единствено што сакала е што побрзо да втаса во новиот дом, но без светот притоа да ја види. Според верувањата, само Господ знае каде момата ќе се омажи, т.е. каде ќ ја 
одведат самовилите. Од таму и пословицата: „Кога се раѓа женцко и стреите плачат“.

Кога невестата за првпат влегува во куќата на мажот, адетот налага да влезе со десна нога. Потоа за чинот на венчавањето во куќата доаѓаат: нункото или кумот, деверот, попот, а за веселба доаѓаат другари, браќа-братучеди и по некој пријател. Невестата за венчанието се променува во убава мариовска носија. Во случајот, вдовицата Доста ги фрла своите ѓупски алишта и се променува со алиштата од претходната почината домаќинка. На главата врзува бел туљбен, става алови кистови, алови прегачи, алови чорапи. Косата ја трга настрана, удира скопци-решмиња, павти-синџири, а на нозете ластикини чевли. При секое нејзино движење налево-надесно, sвечеле синџирите, скопците, павтите. Вдовицата Доста со новата промена се претвора во вистинска убавица. Така променета, невестата останува сама во земникот (визбата) за да ги дочека: попот, нункото, деверот, зетот Илко и неговиот брат Стојо. Тука таа се венчава и сите излегуваат горе бидејќи било адет невенчаната невеста да не се појавува на трпезата пред гостите.

Чинот на венчавањето започнува со венци, вино и поскура (погача). Сопружниците се застанати еден до друг, зад нив нункото со свеќите на нивните рамена, одлево деверот, оддесно старосватот. Попот со благослови и со молитви ги венчава и ќердосува божјите рабини. При кажувањето на овие божествени молитви, зетот и невестата се фаќаат за малите прстиња, за нив се фаќаат деверот и старосватот и заедно со попот се вртат околу бурилото. Откако ќе завртат три пати околу бурилото, чинот на венчањето завршува и младите им бакнуваат рака на сите што учествувале на чинот на венчавањето. По венчавката, гостите ги чекаат младите за веселба, а зетот и невестата им бакнуваат рака на најблиските, а тие се даруваат со по некоја бела меџудија.

За првата брачна ноќ било обичај сопружниците да спијат во земникот од куќата на рогузина со нови покрови со борина за малку светлина и така ја поминувале ноќта. Откако новите сопружници започнувале со нов живот, доаѓал редот за натежнување на невестата и за носење на принова. Според мариовските обичаи, леунките во Мариово лежеле на женскиот кат од куќата на рогузина, со коритце за капење на децата кое го користеле како зглавје. Обичајот налагал на новороденчето да му се назначела задојница, односно жена од селото или блиска роднина на мајката, која првпат ќе го надои новороденото дете. А кога задојницата го задојувала детето, адетот налагал на тој чин да не присуствуваат мажи. На вториот ден од раѓањето на детето се берело сповојница ако првото дете е машко, а ако е женско, не се придавало многу внимание.

Во случајот на Рожденката и Илко Сукалов, иако нивната прва рожба била женско, тие сепак собираат сповојница зашто нивната радост дошла на постари години. Адетот бил само жени да се собираат на сповојницата. Домаќинките ги пречекувале сповојничарките со царевка и грав што ги вареле во големите латвици (големо грне), со топлите булиња (кравајче, малечко лепче) и погачи. Сповојничарките се изредуваат со сите можни и неможни благослови (за новороденчето): 
- „да ни е жив новиот човек“;

- ,до дните - од дните на пците“;

- ,за изгора во село да биде“;

- „папакот да ѝ гори, и нејзе и на таа што ја роди“;

- „ергените по неа да лудат“.

Мајката на новороденото дете ги слуша благословите и заминува, но не присуствува на трпезата зашто се верувало дека може да ѝ секне млекото и за да не ја фатат „навите“ (болест кај жените леунки, која ја предизвикуваат лошите духови - самовилите) како леунка.

Сповојницата не е само смотра за домаќинките, туку се однесува и на самите сповојничарки. И тие носат погачи, булиња, ракии и разни мезиња и од приложеното треба да се види која е пофарк (ербап) во домаќинлакот.

На третата вечер од раѓањето на детето, според мариовските обичаи, иделе наречниците. Во случајот на Доста и Илко Сукалови, тие иделе за да ѝ одредат на „дуда“ пат по кој ќе врви во својот живот. Во глуво доба, пред петли време, во домот на новороденото доаѓале постари жени (стрини), кои се претставувале како наречници. И така започнувало наречувањето со кое на детето му се наречувало да живее господарски. Откако ќе завршеле овие два адети, следно било крштевањето на новороденото, а некрстено дете не можело да се држи повеќ од една-две недели. Во недела детето се носело во црква, каде што нункото го пречекувал со дарови, и попот го прашувал за името на новороденото. Мајката на детето не одела в црква, туку ја наредувала трпезницата и ги пречекувала гостите. Сите овие постапки прикажани во романот нѐ наведуваат да се согласиме дека во верувањата се чуваат, како во некаква архива, остатоци од сите поранешни степени на развој на луѓето (Барјактаревић, 1958, 6). Исто така не треба да нѐ изненади фактот што таквите верувања нашле одраз и во оние дела од македонската проза што го обработуваат животот на нашиот човек во моментите кога тој се судира со поголеми или помали пречки, кои настојува да ги надмине и да ги совлада, на овој или на оној начин.

Во романот е прикажана и прославата на најголемиот верски празник Велигден. Според верувањето, во селото на Велигден рано наутро в црква оделе само старците, мали деца и момчиња и моми што сакале да се причестат. Додека, пак, според верувањата, млади невести и младоженци не се причестувале до годината оти „не биле чисти“. Но, затоа пак, на пладнина се одело в црква со леб, со подароци, ракии, вина, мезиња и тука им било местото на сите, особено на момите. Тука и на орото на сретсело требало да се покаже трудот и мајсторлакот на цела една година: која девојка навезла поубава кошула, исткала поубав прегач, сагија или исплела поубави чорапи.

По велигденскиот ручек се дуеле гајдите на сретсело. Мариовците почнувале со танец. И така, со богата трпеза, со кршење јајца, со песни и ора, го прославувале празникот.

Во овој роман, по правило на сите изразитобитови романи, најпрво е предадена опстановката и односите во кругот на фамилијата. Раскажувањето потоа преминува кон личности и случки надвор од семејната средина, од 
поодделното кон општото и обратно, со постојана меѓусебна преплетеност. Таков е развојниот пат на дејството во романот, кое слично на она од народната приказна, тече спокојно, мирно и богато.

Многу страници од овој роман во себе носат богати етнографски и фолклорни обележја што се добиваат од разновидни подробни описи на материјалниот народен живот, на народните традиции и обичаи. Морам да потенцирам дека тоа богатство од разновидни народни елементи и обележја, оној живо опфатен народен дух, со подробно вистинито сликање на народниот живот, ќе биде најпривлечното нешто за читателот. Оваа литература е секогаш блиска до духот и до средствата на народниот епос и колку и да се тие индивидуално акцентирани, остануваат како нејзина најкарактеристична одлика и нејзина оригинална вредност.

\title{
ЛИТЕРАТУРА
}

БАЈРАКТАРЕВИЋ, М. (1958). Религија и празноверје. Рад: Београд.

ДРУГОВАЦ, М. (1968). „Мариовски летопис (Кон ликовите на Митра и Доста во романот Крпен живот од Стале Попов)“. Современост, 18, бр. 3. Скопје.

МИТРЕВ, Д. (1966). Предговор. Крпен живот, книга II Стале Попов. Скопје: Наша книга.

МИТРЕВ, Д. (1980). Поговор. Крпен живот, книга II Стале Попов. Скопје: Мисла.

\section{Сајтографија}

ГУШЕВСКА, Л. (2009). „Народните верувања како дел од секојдневниот живот (Преку примери од македонската проза)“ https://www.elibrary.ru/item.asp?id=21418367 [Пристапено на 19.03.2021].

ЗДРАВКОВСКИ, Ц. (1997). „Хуманистичките пораки во македонската романескна литература“. Достапно на: http://periodica.fzf.ukim.edu.mk/godzb/GZ50(1997) [Пристапено на 19.03.2021].

Olivera Kaevska

\section{THE CUSTOMS AND BELIEFS IN THE MARIOVO REGION IN THE NOVEL PATCHED LIFE BY STALE POPOV}

\author{
Summary
}

Stale Popov belongs to the first generation of post-war Macedonian writers. Although in older age, he became more involved in prose writing after World War II, leaving behind numerous and valuable works, including his first novel, Patched Life, based on a folk-social theme.

In this paper, I am discussing the customs and beliefs in the Mariovo region shown in the aforementioned novel. The novel gives a broad picture of the Mariovo village life. 
Particular attention is given to the way of life, customs, beliefs of a typical village family in the late 19 and early 20 century.

Many pages of this novel contain rich ethnographic and folklore materials which are derived from various detailed descriptions of material folk life, folk traditions and customs. Especially the ethnographic and folklore data in the novel has been portrayed with great mastery and in a wide variety of settings. 